\title{
ORGANIZATIONAL AND FINANCIAL INSTRUMENTS OF DECENTRALIZATION AND DEVELOPMENT OF UNITED TERRITORIAL COMMUNITIES IN UKRAINE: POLAND'S EXPERIENCE
}

\author{
Taras Vasyltsiv ${ }^{1}$, Iryna Biletska², Olha Mulska ${ }^{3}$ \\ ${ }^{1}$ Doctor of Economics, Professor, Dolishniy Institute of Regional Research of the National Academy of Sciences of \\ Ukraine, Kozelnytska str, 4, Lviv, Ukraine.Email: tgvas77@ukr.net \\ ${ }^{2}$ Doctor of Economics, Associate professor, Ivano-Frankivsk Education and Research Institute of Management of West \\ Ukrainian National University, Dnistrovska str, 32, Ivano-Frankivsk, Ukraine, Email: biletska.iryna@ukr.net \\ ${ }^{3} \mathrm{PhD}$ (Economics), Dolishniy Institute of Regional Research of the National Academy of Sciences of Ukraine, Kozelnytska \\ str, 4, Lviv, Ukraine. Email: oliochka.mulska@gmail.com
}

Received 0204 2021; Accepted 13042021

\begin{abstract}
The formation of balanced budgets and increasing the financial potential of communities, a clear division of powers on the principle of subsidiarity, improving the efficiency of financial resources and stimulating community development have determined the relevance of Ukraine's implementation of best practices in decentralization. The aim of the paper is to analyse the effectiveness of the decentralization process in Ukraine and assess the possibilities of financing the development of united territorial communities, identify the benefits of the Polish experience and determine the areas for their implementation in Ukraine. During the research, the methods of logical generalization and synthesis, comparative analysis, rating and integrated assessment of the financial capacity of the communities in Lviv region of Ukraine were used. Based on the study of foreign, in particular Polish, experience of decentralization, the key reasons for its insufficient effectiveness in Ukraine have been identified. The priority directions of the state policy are proposed and substantiated, and their implementation will allow to increase the efficiency of decentralization in Ukraine.
\end{abstract}

Keywords: decentralization, united territorial communities, financial capacity, economic development, Poland, Ukraine. JEL Classification: H83, P4I.

\section{Introduction}

One of the main goals of local government is to stimulate the development of the local economy. Planning of social and economic transformations requires financial support for infrastructure development, which is closely related to the increase in its maintenance costs, but at the same time contributes to a high level of profitability of the budget of the united territorial communities (UTC). The pace of the social and economic development of UTC is significantly influenced by the level and structure of income of the general fund, which determines the investment capacity and attractiveness of communities. The financial capacity of UTC, which depends on the quality and efficiency of management, is the basis for setting strategic goals for community development, improving the effectiveness of administrative reform.

One of the main problems in the functioning of local self-government is the limited financial resources for current tasks and the implementation of potential investment needs. The reform of budget decentralization is one of the priority areas of structural transformations of the national economy, the effective implementation of which will promote the optimal redistribution of income,

Copyright (C) 2021 Author(s), published by Vytautas Magnus University. This is an open access article distributed under the terms of the Creative Commons Attribution Non-Commercial 4.0 (CC BY-NC 4.0) license, which permits unrestricted use, distribution, and reproduction in any medium provided the original author and source are credited. The material cannot be used for commercial purposes. 
the delegation of powers between levels of government and provide funding for social programs. The main direction of decentralization is the formation of financially affluent communities with investment opportunities to meet the needs of residents and provide the quality public services.

In recent years, the issue of decentralization, its risk assessment, formation of priority areas for the development of UTC is a broad subject of scientific discourse. Scientists at Lviv School of Regional Studies have shown high interest in the issues of financial capacity and development of UTC, and the efficiency of decentralization implementation $[3 ; 12 ; 13 ; 14]$, and they conducted a comprehensive study of the impact of financial decentralization on the economic development of UTC in both Central and Western Ukraine. Scientific publications by Lytvynchuk, I., Skydan, O., Ivaniuk, O. [11], Vasyltsiv T. [15], Yeshchenko, M., Fasolko, T., Dolgalova, O. [16] are devoted to the study of theoretical and applied aspects of decentralization. Numerous studies of the relationship between the state policy of decentralization and social and economic development of territories, including those based on the European practices of smartspecialization, are revealed in the works of Akai, N., Sakata, M [1], Blöchliger, H., Égert, B., Fredriksen, K. [4], Börzel, T. \& Langbein, J. [6], Edwards, B. [5; 9], Cantarero D. [7], Lin J. [10].

Most research and suggestions in this area have a systemic theoretical nature, without practical significance for the

development of regional development programs, as they were carried out and formed because of analysis of decentralization risks in some territories of Ukraine, without studying the experience of European countries. Therefore, it is especially important to study the best world practices for the implementation of organizational and financial instruments and measures to improve financial decentralization for their implementation in Ukraine. Poland's experience is the most acceptable for the national economy.

The aim of the paper is to analyse the effectiveness of the decentralization process in Ukraine and assess the possibilities of financing the development of UTC, identify the benefits of the Polish experience and distinguish areas for their implementation in Ukraine.

The object of the study is the financial capacity of UTC and decentralization processes in Poland, which can be implemented in Ukraine.

\section{Method of the research}

To assess the financial capacity of UTC, an integral approach was used, which can be applied to build an empirical indicator of financial opportunities for community development. In order to build an integral coefficient of financial capacity of UTC in 2020, 8 indicators were selected (Fig. 1), which show the state of financial support for the development and investment potential of UTC. 


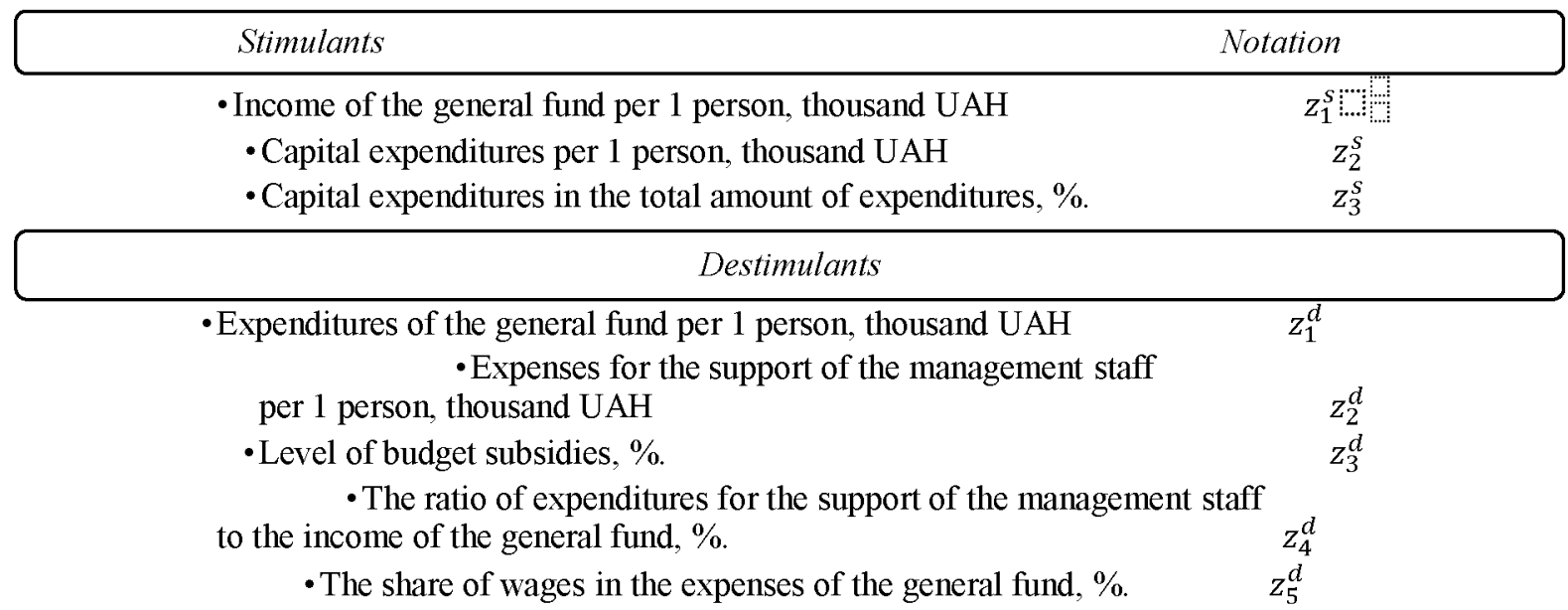

Figure 1. UTC financial capacity indicators

(Developed by the authors)

The method of constructing an integral indicator of UTC's financial capacity involves the implementation of three stages, namely 1) normalization of indicators within the set of UTC; 2) calculation of coefficients of weight significance of indicators; 3 ) assessment of the integral coefficient of financial capacity of UTC.

The normalization of indicators within the set of UTC is calculated by formula (1) for stimulants and by formula (2) for destimulants.

$$
\begin{aligned}
& b_{i n}^{s}=z_{i n} / a_{i n}^{\max }, \\
& b_{i n}^{d}=a_{i n}^{\min } / z_{i n},
\end{aligned}
$$

where $b_{i n}^{s}, b_{i n}^{d}$ are normalized values of $i$-th indicator of $n$-th UTC; $z_{i n}$ is the initial value of $i$-th indicator of $n$ - $t h \mathrm{UTC} ; a_{i n}^{\max }, a_{i n}^{\min }$ are maximum and minimum value of $i-t h$ indicator of $n$-th UTC.

The coefficients of weight significance of indicators are determined on the basis of the principal component analysis, which allows to eliminate the heterogeneity of the constructed series of indicators. A necessary condition for calculating the weights of the indicators is compliance with the appropriate equality (formula 3).

$$
\left\{\begin{array}{c}
w_{i}<1, \\
\sum_{i=1}^{j} w_{i}=1,
\end{array}\right\}
$$

where $w_{i}$ is the weight of $i$-th indicator; $j$ is the number of $i$-th indicator.

The integral coefficient of financial capacity of UTC (formula 4) is calculated by the weighted average method as a linear combination of indicators and weights.

$$
I F O_{n}=\sum_{i=1}^{j} w_{i} * b_{i n}
$$

where $I F O_{n}$ is an integral indicator of the financial capacity of $n$ - $t h$ UTC.

In the process of research, the additional methods of logical generalization and synthesis are used for formation of the basic conclusions and offers of research; comparative analysis is for comparison of the intensity of administrative reform in Ukraine and Poland; rating is for visualization of region ratings in Ukraine according to the level of affluent communities.

\section{Results and discussion}

Building a system of delegation of powers and financial resources at the level of local governments is an important task of decentralization; its effective implementation will help meet the needs of local residents. In this context, financial and administrative decentralization are prerequisites for the development of UTCs, factors in ensuring their capacity. At the same time, a significant risk of UTC development is the growth of their financial dependence on budget funds, an increase of the subsidy level of the local 


\section{sciendo}

Management Theory and Studies for Rural Business and Infrastructure Development

eISSN 2345-0355. 2021. Vol. 43. No. 2: 276 - 287

Article DOI: https://doi.org/10.15544/mts.2021.24

budget, a decrease of investment attractiveness. In particular, a significant impact is observed in some regions of Ukraine. Thus, at the beginning of 2020,1029 UTCs were created in Ukraine, which is 6.5 times higher than the corresponding coefficient during 2014-2019. The number of residents living in UTC in 2020 was 11.7 million people (about $34 \%$ of the total population of the country). UTC's financial revenues in 2019 amounted to about UAH 270 billion, which is an increase of $14 \%$ or UAH 32.9 billion compared to 2018. The share of UTC local budgets' own revenues in 2019 was $6.8 \%$. For comparison, this share for 2014-2019 increased from $5.1 \%$ to $6.8 \%$ (or 1.7 percentage points).

The critical gaps in the legal framework for the functioning of UTC in Ukraine are the lack of a new version of regulations on service in local government, particularly in terms of regulating these issues and in encouraging the population to employment and self- development to work in local government, ensuring the proper level of prestigiousness of such work; the need to improve the system of state supervision, control and correction of decisions by local governments if they contradict the principles and guidelines of state policy in the field of national security.

In the regional aspect, the development of decentralization processes in Ukraine is not balanced (Fig. 2). It is noteworthy that only about $50 \%$ of the total amount of necessary processes has been implemented in Ukraine. For example, in the leading regions there is a high level of decentralization implementation, while in some regions the share of the population of affluent communities does not exceed $50 \%$, in most regions the share of affluent communities is less than a half, and in 18 regions the share of territorial communities that are not joined does not exceed $40 \%$.

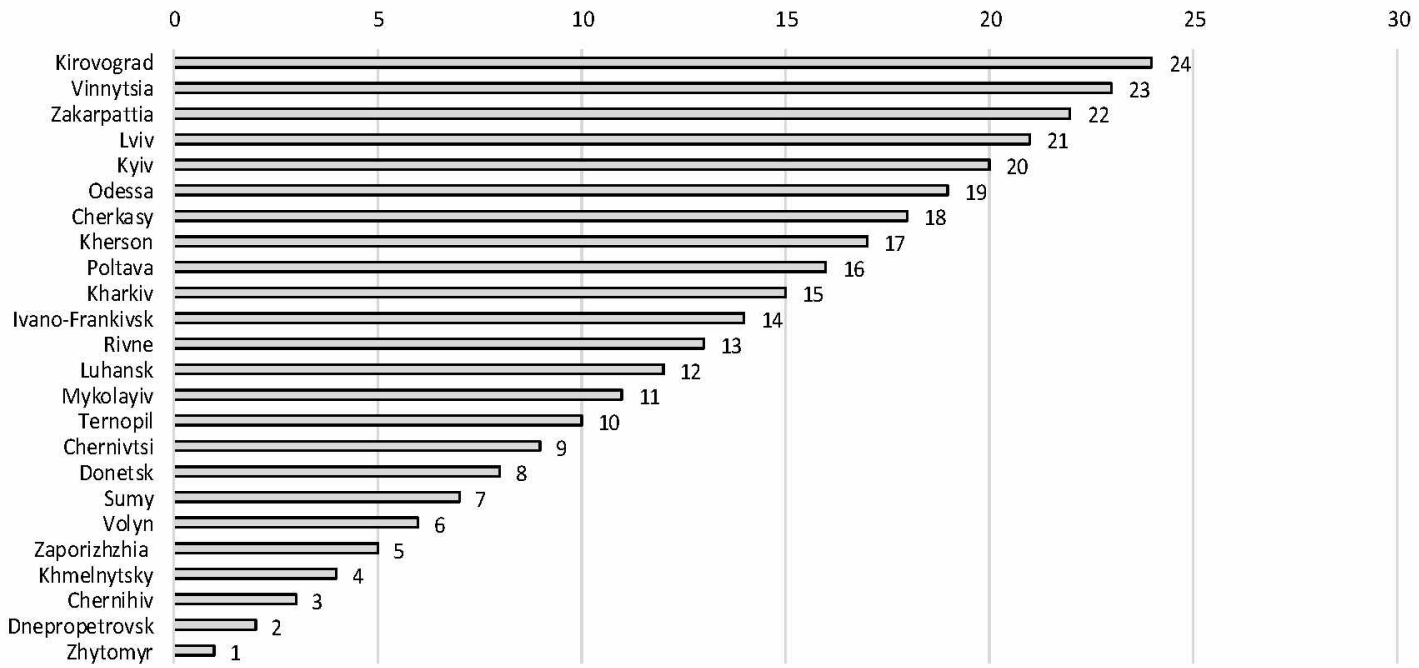

Figure 2. Indicators of ranking the regions of Ukraine by the formation of affluent communities, 2020 (Developed by the authors based on [7])

Note: without considering the temporarily occupied territories of the Autonomous Republic of Crimea, Donetsk and Luhansk region

Copyright (C) 2021 Author(s), published by Vytautas Magnus University. This is an open access article distributed under the terms of the Creative Commons Attribution Non-Commercial 4.0 (CC BY-NC 4.0) license, which permits unrestricted use, distribution, and reproduction in any medium provided the original author and source are credited. The material cannot be used for commercial purposes. 
In Donetsk, Kharkiv, Odesa, Kyiv, Zakarpattia and Kirovohrad regions, the share of the districts' amount where the processes of voluntary unification (accession) of territorial communities have not started yet exceeds $30 \%$; the share of UTCs with a population of less than 5,000 remains low (the national average was $34.8 \%$ ); in Luhansk, Lviv and Kirovohrad regions there are no UTCs with administrative centers in cities of regional significance; in Cherkasy, Odesa, Kyiv, and Vinnytsia regions, more than $20 \%$ of territorial communities do not have long-term development plans.

The financial capacity of UTC depends on certain cost financial instruments, including investment costs that help increase the investment attractiveness of the community, attract investment in social infrastructure. Ensuring a high level of community infrastructure is one of the main factors in the development of UTC. Financial means to stimulate the infrastructure development concern, first of all, support and expansion of technical infrastructure (water supply, sewerage, electricity and heat supply, public transport) and social infrastructure (education, culture, health care). Investing in infrastructure strengthens the position of the commune in terms of attracting potential investors. Infrastructure tools create the conditions for increasing the competitiveness of the territorial unit by improving the quantity and quality of provided communal and social services, creating conditions for the placement of new economic entities. The investment activity of local self-government units differs significantly from the investment activity of economic entities, as it is carried out in order to ensure a high level of financial capacity of UTC.

For example, in Lviv region, the indicators of UTC's financial capacity in 2020 (Table 1), calculated on the basis of the author's methodology, varied in the range from 0.665 to 0.166 , which indicates a significant differentiation of community development in the region (Fig. 3). Slavske UTC, which has the highest indicators among the studied communities of financial capacity, demonstrates high rates of development, and conversely, Volytsk UTC with the lowest indicators of financial capacity shows insignificant rates of efficiency.

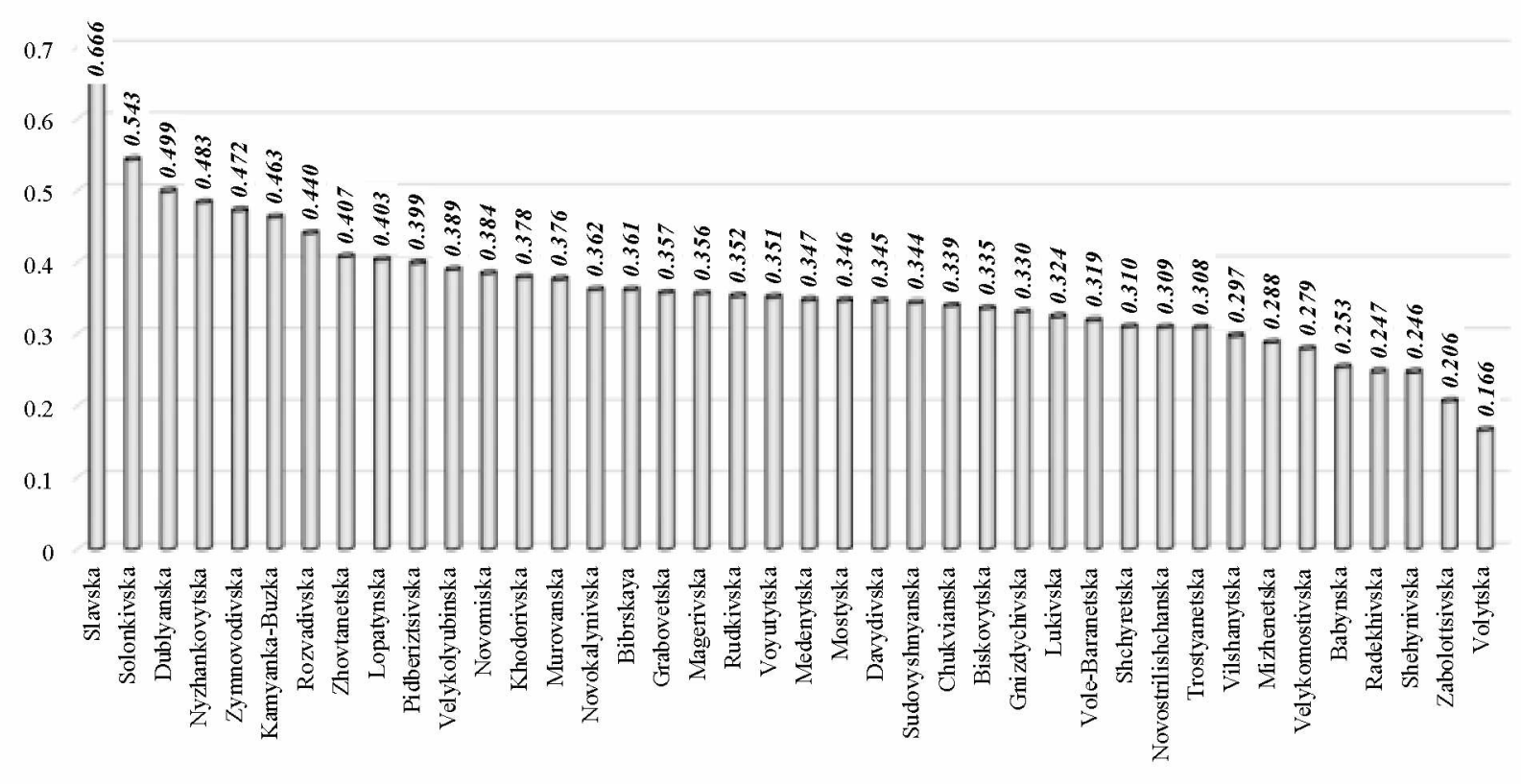

Figure 3. The level of financial capacity of UTC in Lviv region, 2020 (Developed by the authors) 


\section{sciendo}

Management Theory and Studies for Rural Business and Infrastructure Development

eISSN 2345-0355. 2021. Vol. 43. No. 2: 276 - 287

Article DOI: https://doi.org/10.15544/mts.2021.24

It should be emphasized that the development of UTC is significantly influenced by certain indicators of financial capacity. Thus, the largest impact, which can be determined by the coefficient of weight significance, has the indicator of "Income of the general fund per person" (17.87\%) and "Expenditures of the general fund per person" $(15.26 \%)$, which indicates a high dependence of financial capacity of communities from the effectiveness of the implementation of financial instruments for the development of UTC (Fig. 4). Instead, the "Level of budget subsidies" has a low level of importance for ensuring the financial capacity of UTCs, which is a confirmation of the thesis about the importance of financial autonomy of communities to ensure the effectiveness of decentralization in Ukraine.

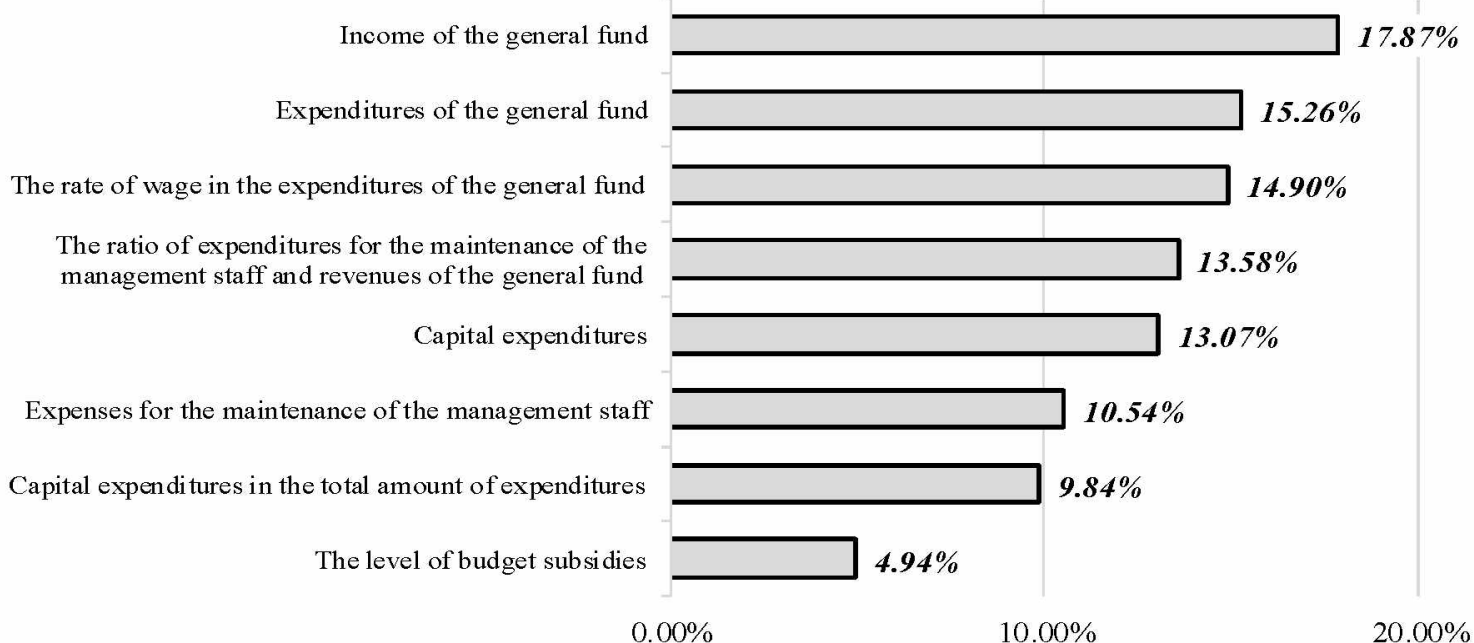

Figure 4. Coefficients of weight significance of the indicator of financial capacity of UTC in Lviv region, 2020

(Developed by the authors)

The results of the analysis of the financial capacity indicator, on the example of UTC of Lviv region, confirm the thesis about the low efficiency and intensity of the decentralization process in Ukraine. International experience in decentralization is important, especially in those countries where an administrative reform has been rapid and highly effective. In particular, the experience of the Polish model of decentralization can be considered as the most acceptable for Ukraine. Thus, in the Republic of Poland, the processes of decentralization in accordance with the principles and regulations of the European Charter of Local Self-Government began much earlier. The main innovations in public administration at the local level took place after the adoption of the new Constitution of Poland (17.10.1997), and its regulations defined the scope of responsibilities of local governments with all tasks that are not directly assigned by law to higher authorities. In 1998, the local self-government reform was carried out, which consisted of the creation of two higher levels of state executive bodies such as the county and the province, as well as the change in the territorial form and number of provinces. The year 1999 was especially important, when a new administrative and territorial reform was implemented and the

Copyright (C) 2021 Author(s), published by Vytautas Magnus University. This is an open access article distributed under the terms of the Creative Commons Attribution Non-Commercial 4.0 (CC BY-NC 4.0) license, which permits unrestricted use, distribution, and reproduction in any medium provided the original author and source are credited. The material cannot be used for commercial purposes. 
division into statistical regions according to the nomenclature of regions of the European Union (NUTS) was done. The administrative division consolidated 16 provinces, 308 counties and 2,489 communes, including 65 cities with the status of urban counties. A characteristic feature of the decentralized system of public administration was the creation of local government, which has a unit fundamentally separated from the central government called the commune. Residents of the commune are given the opportunity to form a territorial community based on the fact of living in a certain area. The supreme body of the commune became the commune council, which is formed by elections. Concerning the financial decentralization, the state expenditures on local council budgets have been replaced by the budgets of the new territorial units, which have also become economic units.

The most difficult political problem was the delimitation of new territorial units, as the reform led to the abolition of most administrative regions, which led to the degradation of regional capitals, political and administrative elites, and the deformation of relationship between business and political structures. The reform, although not fully, contributed to the unification of the organizational structure of Poland, but ensured its transformation from departmental and territorial structure to merely territorial one. This has helped bring Poland closer to the European standards of territorial organization and the structure of public administration at the local level, based on the principles of building civil society, efficiency, transparency, subsidiarity, openness, accountability and flexibility.
The reform of the public administration system at the local level made it possible to form a new administrative system in Poland. The system of public administration at the local level in Poland has become three-tier and includes a commune (community), a county (district) and a province. It is worth emphasizing the main tasks (functions) that are distributed at different levels of local selfgovernment in Poland (Fig. 5). 


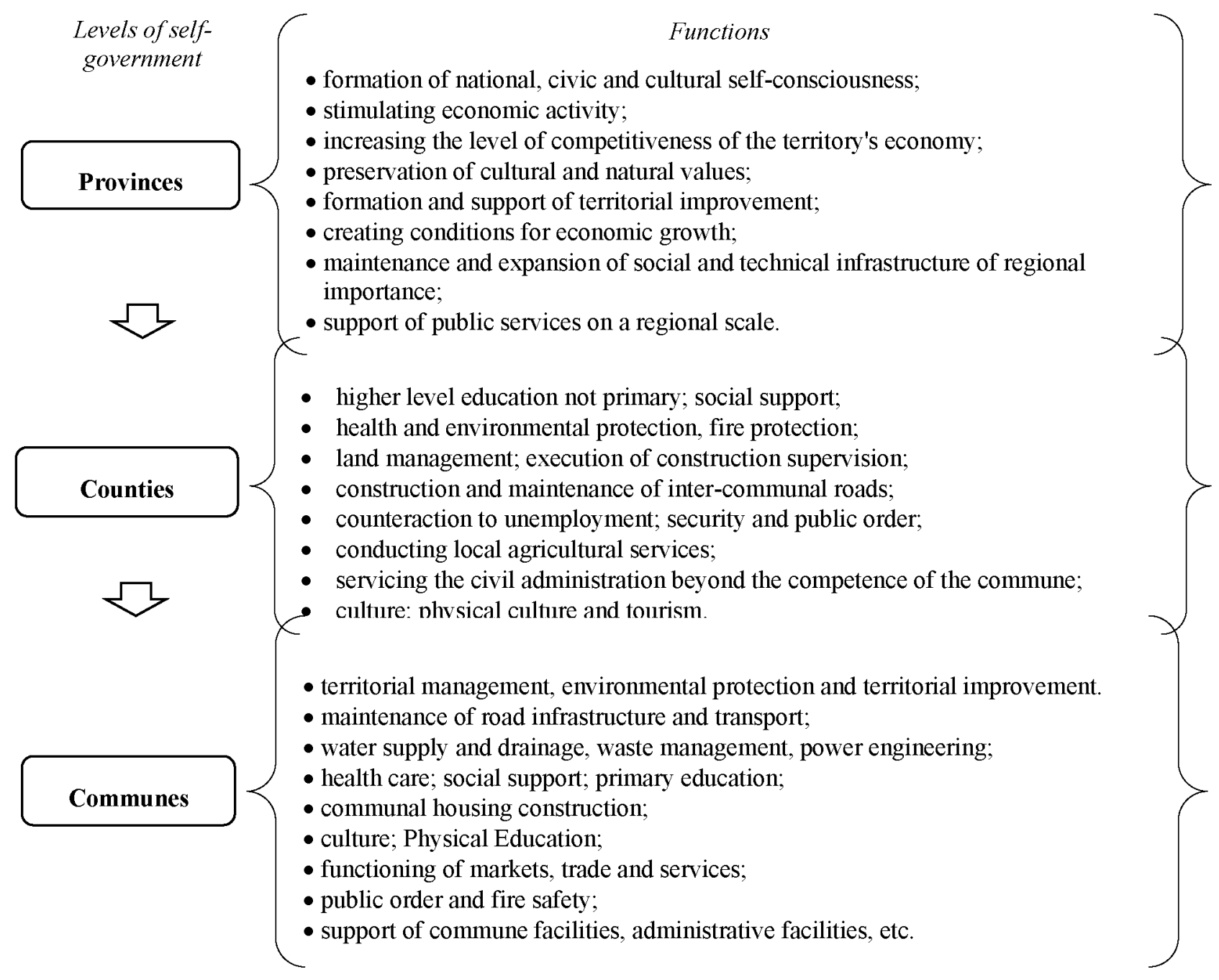

Figure 5. Institutional support of local self-government in the Republic of Poland (Developed by the author based on data [2, p. 29])

As a result of generalization of tendencies and intensity of decentralization in Ukraine, and also the Polish experience of administrative reform the perspective directions of the state policy of formation of administrative system in Ukraine taking into account the best practice of Poland are defined (Fig. 6). 


\section{sciendo}

Management Theory and Studies for Rural Business and Infrastructure Development

eISSN 2345-0355. 2021. Vol. 43. No. 2: 276 - 287

Article DOI: https://doi.org/10.15544/mts.2021.24

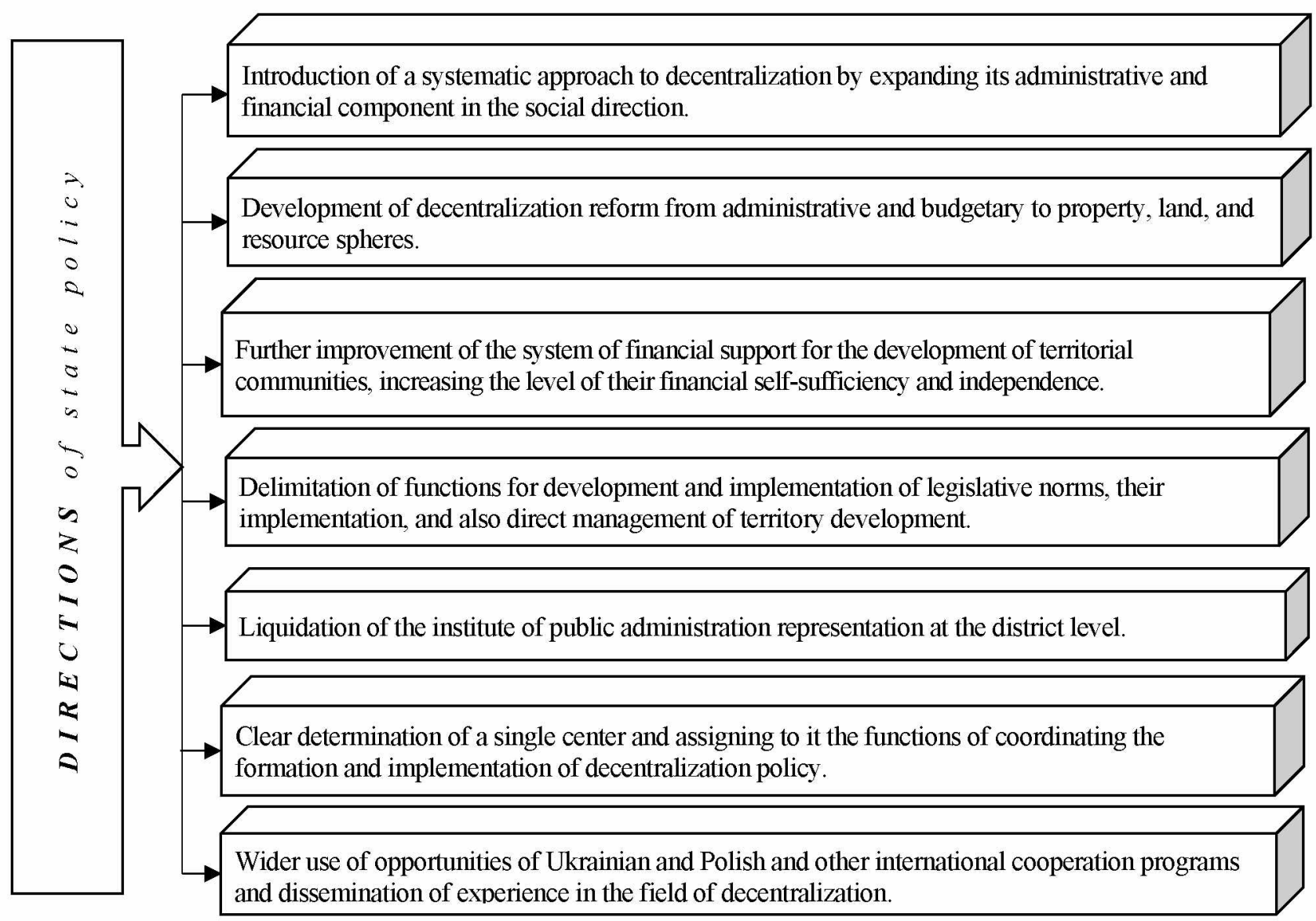

Figure 6. Perspective directions of implementation of the experience of the Republic of Poland's decentralization in Ukraine

(Developed by the authors)

The priority and key direction for Ukraine should be the introduction of a systematic approach to administrative reform, which is based on the expansion of administrative and financial decentralization in its social direction. A significant institutional advantage of the Polish experience of decentralization is that it was not only administrative, territorial and financial decentralization, but also implemented nine areas of reforming within a single package of the Plan by L. Balcerowicz. Accordingly, changes in the areas of education, health care, medicine, housing and communal services, and infrastructure have been implemented in the regulations of administrative and territorial decentralization. In Ukraine, disparate reforms are being implemented in these and other areas, which are not coordinated strategically, politically and economically, or even in time.

Using this element of the Polish experience would significantly increase the efficiency of decentralization in Ukraine and intensify the pace of its implementation, as the entities benefit at all levels of relations, especially central, local, community, individual ones. For example, in the field of health care, in parallel with decentralization in Poland, changes have been implemented, according to which the unemployed and other socially vulnerable groups receive support from the state, and the local population get it

Copyright (C) 2021 Author(s), published by Vytautas Magnus University. This is an open access article distributed under the terms of the Creative Commons Attribution Non-Commercial 4.0 (CC BY-NC 4.0) license, which permits unrestricted use, distribution, and reproduction in any medium provided the original author and source are credited. The material cannot be used for commercial purposes. 
through taxes to the National Health Fund. The salaries of medical workers are provided at the lowest level, and at the central level, programs for the development of the medical system are implemented, as well as health care facilities are maintained.

In the field of education, educational institutions were maximally decentralized, when they were owned exclusively by local governments. They fully determine the content of educational and training programs. However, the centralized ministry fixes the list of exams and assessment criteria.

An important area of implementation of Poland's experience in the field of decentralization in Ukraine is the widespread use of Ukrainian and Polish and other international programs of cooperation and dissemination of experience in the field of decentralization. For example, at the stage of decentralization reform, Poland more actively and widely provided financial, expert, information and communication and other support in this area both through international cooperation and its own programs by directly delegating and monitoring the implementation of such tasks to the Polish Ministry of Foreign Affairs.

The third strategic direction envisages a clear determination of a single center and assigning functions to it regarding the coordination of the formation and implementation of decentralization policy in Ukraine. It is said that, in contrast to Poland, where one of the main organizational and managerial factors for the success of decentralization reform has been the existence of "single headquarters of reforms", Ukraine has a large number of such centers, but at the same time they are absent at the regional and local levels. Thus, there is a "dragging" of the initiative from some structures and coordinating councils of reforms to others, excessive turn in decision-making at the central level as to the local one (a clear example was the compulsion to unite a number of settlements to others, such as Great Lviv). Thus, the Ukrainian and Polish experience has shown that it is difficult to solve problems without a single center of reform.

In Ukraine, during the planning of the decentralization reform, some of the changes were hidden and thus the real reforming was replaced by its imitation. So, in Ukraine, district state administrations have been preserved, while in Poland, at the county level, central government representations have been abolished, and the institution of province has been left only at the province level. Therefore, there is a need to eliminate the institution of public administration at the district level. In Ukraine, the establishment of the institution of the perfect (as a form of presidential administration) is expected, which causes public controversy over the resumption of centralization of power.

It is important to differentiate in Ukraine the functions of development and implementation of legislative norms, their implementation, as well as direct management of territorial development. Thus, in Poland, a corresponding principle was enshrined in law, according to which people who developed the decentralization reform were not entitled (as well as members of their families) to participate in the management of local communities for 10 years after the introduction of reforms. Instead, there are no such restrictions in Ukraine. Numerous reforms are being developed by the Cabinet of Ministers of Ukraine, which contradicts the law, as the Cabinet of Ministers of Ukraine is not a legislative body. The existence of such gaps, despite corruption, leads to a conflict of interests at various levels of government. It is appropriate to differentiate legally both the relevant structures and the persons who develop laws, implement laws and carry out public administration.

Ukraine should also use the experience of Poland to ensure further improvement of the system of financing the development of territorial communities, increasing the level of their financial self-sufficiency and independence. Thus, after the introduction of budgetary and financial decentralization, territorial communities received much more financial resources for the implementation of territorial development programs, in particular, increasing the share of own revenues.

It is worth emphasizing the importance of implementing effective practices of the Polish experience, in particular, consolidating guaranteed incomes at the legislative level. 
These are, in particular, own revenues and transfers from the center (real estate tax); a part of the corporate income tax in the community; a part of the personal income tax. Systematic practice in Poland is financial support and cooperation between provinces.

The use of the Polish experience in extending decentralization reform from the administrative and budgetary sphere to the property, land and resource spheres can be no less relevant and in fact a continuation of the policy to improve financial opportunities of communities. In fact, it is difficult for the realities in Ukraine. However, in the case of such changes it would give a tremendous impact on the social and economic development of areas, especially weak and depressed ones. In Poland, all property and land (except for strategically important facilities) were transferred to the ownership of the communes. This was an impetus to the development of the communal real estate market and community banking services. Accordingly, communities received the necessary resources for their functioning and further progress.

\section{Conclusions}

The speed, intensity and quality of reforms in Ukraine are insufficient to ensure a high level of efficiency in the decentralization process. Based on the experience of decentralization in Poland, promising areas of public policy have been identified, their implementation will increase the effectiveness of decentralization in Ukraine, namely the introduction of a more systematic approach within decentralization reform, expansion of administrative and financial decentralization in the social direction; wider use of opportunities of Ukrainian and Polish and other international programs of cooperation and dissemination of experience in the field of decentralization; clear determination of a single center and assigning to it the functions of coordinating the formation and implementation of decentralization policy; liquidation of the institute of public administration representation at the district level; delimitation of functions of development and implementation of legislative norms, their realization, and also directly management of development of territories; further improvement of the system of financial support for the development of territorial communities, increasing the level of their financial self-sufficiency and independence; development of decentralization reform from administrative and budgetary to property, land and resource spheres.

\section{References}

Akai, N., \& Sakata, M. (2002). Fiscal decentralization contributes to economic growth: evidence from state-level cross-section data for the United States. Journal of Urban Economics, 52 (1), 93-108. https://doi.org/10.1016/S00941190(02)00018-9

Biletska, I.M. (2020). Directions of implementation of the Polish experience in the context of increasing the effectiveness of the state policy of decentralization and ensuring the socio-economic development of Ukraine. State and regions, 4 (115), 25-32.

Bil, M., \& Levytska, O. (2019). Potential of employment activation in the amalgamated territorial communities of the western and central regions of Ukraine. Efficient economy, 12, https://doi.org/10.32702/2307-2105-2019.12.92

Boex, J., \& Edwards, B. (2016). The (Mis-) Measurement of Fiscal Decentralization in Developing and Transition Countries: Accounting for Devolved and Nondevolved Local Public Sector Spending. Public Finance Review, 44(6), 788-

Copyright (C) 2021 Author(s), published by Vytautas Magnus University. This is an open access article distributed under the terms of the Creative Commons Attribution Non-Commercial 4.0 (CC BY-NC 4.0) license, which permits unrestricted use, distribution, and reproduction in any medium provided the original author and source are credited. The material cannot be used for commercial purposes. 
810. https://doi.org/10.1177/1091142115616183.

Börzel, T. \& Langbein, J. (2019). Core - periphery disparities in Europe: is there a link between political and economic divergence? West European Politics, 42 (5), 941-964. https://doi.org/10.1080/01402382.2018.1558534.

Cantarero-Prieto, David \& Gonzalez, Patricio. (2009). Fiscal Decentralization and Economic Growth: Evidence from Spanish Regions. Public Budgeting \& Finance, 29 (4). DOI: 10.1111/j.1540-5850.2009.00941.x.

Decentralization provides opportunities. URL : https://decentralization.gov.ua/

Edwards, Benjamin \& Yilmaz, Serdar \& Boex, Jameson. (2015). Decentralization as a Post-Conflict Strategy:

Local Government Discretion and Accountability in Sierra Leone. Public Administration and Development, 35(4). DOI: 10.1002/pad.1707.

Lin, J., \& Liu, Z. (2000). Fiscal decentralization and economic growth in China. Economic Development and Cultural Change, 49 (1), 1-21. https://doi.org/10.1086/452488

Lytvynchuk, I., Skydan, O., \& Ivaniuk, O. (2021). Local governance and territorial development on the basis of gis. Management Theory and Studies for Rural Business and Infrastructure Development, 42(4), 422-433. https://doi.org/10.15544/mts. 2020.43

Storonyanska, I. \& Benovska, L. (2017). Risks of administrative and financial decentralisation: theoretical hypotheses and empirical assessment. Economic Annals-XXI, 166 (7-8), 76-79. https://doi.org/10.21003/ea.V166-15.

Storonyanska, I., Patytska, K., Hrynchyshyn, I., \& Chemerys, V. (2020). Spatial disproportions in development of territorial community under conditions of administrative and financial decentralization. Agricultural and Resource Economics: International Scientific E-Journal, 6(4), 43-62. https://doi.org/10.51599/are.2020.06.04.03

Stosnyanskaya I. Z (ed) (2019). Socio-economic development of territorial communities of central Ukraine in conditions of decentralization: scientific and analytical report. Dolishniy Institute of Regional Research of NAS of Ukraine. Lviv. URL: http://ird.gov.ua/irdp/p20190040.pdf

Vasyltsiv, T., Levytska, O., Lupak, R., Gudzovata O., Kunytska-Iliash M., Zaychenko, V., \& Mulska, O. (2021). Understanding creative, information and knowledge determinants of the economic growth of the EU regions within smart development strategies. Management Science Letters, 11 (2021), 1295-1308. DOI: 10.5267/j.msl.2020.11.009.

Yeshchenko, M., Fasolko, T., Dolgalova, O., Mykhalchenko H., \& Udovychenko, I. (2021). Legal provision of the state administration of the ecological component of sustainable socio-economic development. Management Theory and Studies for Rural Business and Infrastructure Development, 42(4), 415-421. https://doi.org/10.15544/mts.2020.42 